\title{
First Record of a Pearlfish, Carapus mourlani, Inhabiting the Aplysiid Opisthobranch Mollusc Dolabella auricularia ${ }^{1}$
}

\author{
Peter W. Glynn, ${ }^{2,3}$ Ian C. Enochs, ${ }^{3}$ Fohn E. McCosker ${ }^{4}$ and Abigail N. Graefe ${ }^{5}$
}

\begin{abstract}
Adult individuals of the pearlfish Carapus mourlani (Petit, 1934) occur commonly in the mantle cavity of the opisthobranch mollusc Dolabella auricularia (Lightfoot, 1786) in shallow marine waters of the Gulf of Chiriquí, Pacific Panamá. Nearly $30 \%$ of the molluscan hosts collected during the day on a coral reef contained one or two fish. Feeding observations of a captive fish as well as the intact condition of the host's ctenidium and other internal organs suggest that $C$. mourlani is an inquiline commensal and not parasitic. Fish curl around the ctenidium during the day and capture microcrustaceans when the fish emerge from their host at night to feed. From low-light infrared video recordings, Carapus was observed to accurately grasp rapidly swimming amphipods in nearly total darkness and ingest them. This symbiotic relationship appears to benefit Carapus by allowing the fish to avoid predators during the day and to forage at night.
\end{abstract}

Carapid pearlfishes are free-living, commensal inquilines or parasitic (Trott 1981, Parmentier and Vandewalle 2005). Those that are inquiline commensals are reported to occupy holothurians, sea stars, or bivalve molluscs (Trott 1970, Markle and Olney 1990, Paredes-Rios and Balart 1999). The terminology adopted herein follows Castro (1988). Symbiosis is defined as a close heterospecific association irrespective of harm or benefit to the partners. Commensals are symbionts with no metabolic dependency (e.g., food, growth factors) between the members of the association. Inquilines refer to associ-

\footnotetext{
${ }^{1}$ Support was provided by U.S. National Science Foundation grant OCE-0526361 and earlier awards. Manuscript accepted 26 October 2007.

${ }^{2}$ Corresponding author (e-mail: pglynn@rsmas .miami.edu).

${ }^{3}$ Division of Marine Biology and Fisheries, Rosenstiel School of Marine and Atmospheric Science, University of Miami, 4600 Rickenbacker Causeway, Miami, Florida 33149-1098.

${ }^{4}$ California Academy of Sciences, San Francisco, California 94118-4599.

${ }^{5}$ Marine and Atmospheric Science Program, University of Miami, Coral Gables, Florida 33124-0411.
}

Pacific Science (2008), vol. 62, no. 4:593-601

(C) 2008 by University of Hawai'i Press

All rights reserved ates that shelter within (but not inside the body cavity of ) the host. Some carapid species enter the coelom of their hosts, but this was not observed in Carapus mourlani in our study.

It has also been suggested, but not demonstrated, that some carapids facultatively occupy polychaete worm tubes (Williams and Shipp 1982) and sponges (Ayling and Cox 1982). Many ophidiiformes possess a propensity for finding shelter in a variety of inanimate substrates and as such their hiding behavior in a particular host can be described as facultative rather than obligate (Svetovidov 1961, Markle and Olney 1990). This is the first report of a pearlfish, Carapus mourlani (Petit, 1934), inhabiting the mantle cavity of a large opisthobranch mollusc, Dolabella auricularia (Lightfoot, 1786), in the Gulf of Chiriquí, Panamá.

Four species of carapids are recognized from the eastern tropical Pacific (Markle and Olney 1990, Parmentier et al. 2006). They are Echiodon exilium (Rosenblatt, 1961), which are free-living as adults; Carapus dubius (Putnam, 1874), which inhabits bivalve molluscs; Carapus mourlani, an associate of sea stars and holothurians (Markle and Olney 1990); and Encheliophis vermicularis (Muller, 1842), an obligate parasite of the holothurian Actinopyga lubrica (Sluiter). 
Carapus mourlani was first reported from the eastern Pacific on the basis of specimens found to inhabit the sea cucumber Isostichopus fuscus (Ludwig) off the Ecuador coast (Parmentier et al. 2006). Twelve $C$. mourlani were found within the coelomic cavity, respiratory tree, or digestive tracts of the 4,345 $(0.28 \%)$ I. fuscus that were collected between depths of 5 and $60 \mathrm{~m}$ and examined. Carapus mourlani is widely distributed in the tropical Indo-Pacific from East Africa to Hawai' $i$ and throughout Micronesia. In the central to western Indo-Pacific it is known to inhabit the asteroids Culcita novaeguineae Müller \& Troschel, Pentaceraster cumingi (Gray), Choriaster granulatus Lütken, and Acanthaster planci (Linnaeus) and the holothurians Stichopus variegatus Semper, Stichopus chloronotus Brandt, Bobadschia argus Jäger, Actinophya muritiana (Quoy \& Gaimard), and Holotburia scabra Jaeger (see Markle and Olney 1990).

\section{MATERIALS AND METHODS}

Dolabella auricularia, a member of the opisthobranch family Aplysiidae, is an uncommonly large sea slug easily recognized by its truncated posterior border, which forms a sloping, disklike shield with elongated simple papillae covering the dorsum (CamachoGarcía et al. 2005). Dolabella is the largest sea hare present in the tropical Indian and Pacific oceans, reaching $0.5 \mathrm{~m}$ in length. It is widely distributed from the Red Sea to the tropical eastern Pacific, including the Hawaiian and Galápagos islands (Gosliner et al. 1996). Carapus mourlani, family Carapidae, is a common species and differs from other carapids in its dentition, swimbladder morphology, and coloration. It reaches $17 \mathrm{~cm}$ in total length (Markle and Olney 1990).

The majority of the symbionts were captured during the day in 25- to 30-litervolume mesh bags of Pocillopora spp. coral rubble anchored at 3-6 $\mathrm{m}$ depth on the seaward side of the Uva Island coral reef. The coral reef is on the west side $\left(07^{\circ} 49^{\prime} \mathrm{N}, 81^{\circ}\right.$ $46^{\prime} \mathrm{W}$ ) of Uva Island in the Gulf of Chiriquí, Pacific Panamá (Figure 1). The bundles of rubble were located about $5 \mathrm{~m}$ downslope from the reef framework. Collections were made from 2002 to 2005, the first 6 months after emplacement of the rubble bags, then at yearly intervals thereafter. Dolabella and Carapus were also collected at 4-6 $\mathrm{m}$ depth along the south shore of the Uva Island embayment when the opisthobranch host emerged at night. The presence of Carapus inhabiting Dolabella was determined when the oxygen concentration declined and the fish exited the host. The emerging fish were then quickly revived with frequent water changes and aeration. Symbionts employed in long-term observations were reintroduced to their hosts and maintained in flow-through aquariums until shortly before departure to Miami, Florida. About $4 \mathrm{hr}$ before the flight, symbiont-host pairs were placed in polyethylene bags containing approximately 1 liter of filtered seawater and 2 liters of $100 \%$ oxygen. Bagged specimens were placed inside a large cooler and transported as cargo aboard a flight to Miami. Upon arrival, the symbionts were immediately moved to flow-through aquariums at the Rosenstiel Marine School, University of Miami.

Animals were maintained in powdercoated, metal screen-covered (to prevent escape) 40-liter aquariums supplied with seawater from Biscayne Bay. Aquariums were kept in subdued lighting during the day and in darkness at night. Large rocks were placed in each aquarium to provide shelter for the cryptic habit of the molluscan hosts. The hosts were fed several times a week with green filamentous (Derbesia sp.) and brown Stypopodium zonale algae. The algae were collected from Biscayne Bay and contained abundant associated microfauna.

Observations on the exit and entrance behavior of several fish were conducted during the day and night. Behavioral observations in aquariums were obtained with a remote, night-vision, digital video recorder (DVR). An infrared (IR) LED (light-emitting diode) illuminator was positioned over an aquarium and programmed to turn on automatically at low light levels, beginning before sundown and ending after sunrise. A low-light IRsensitive bullet camera was connected to a 


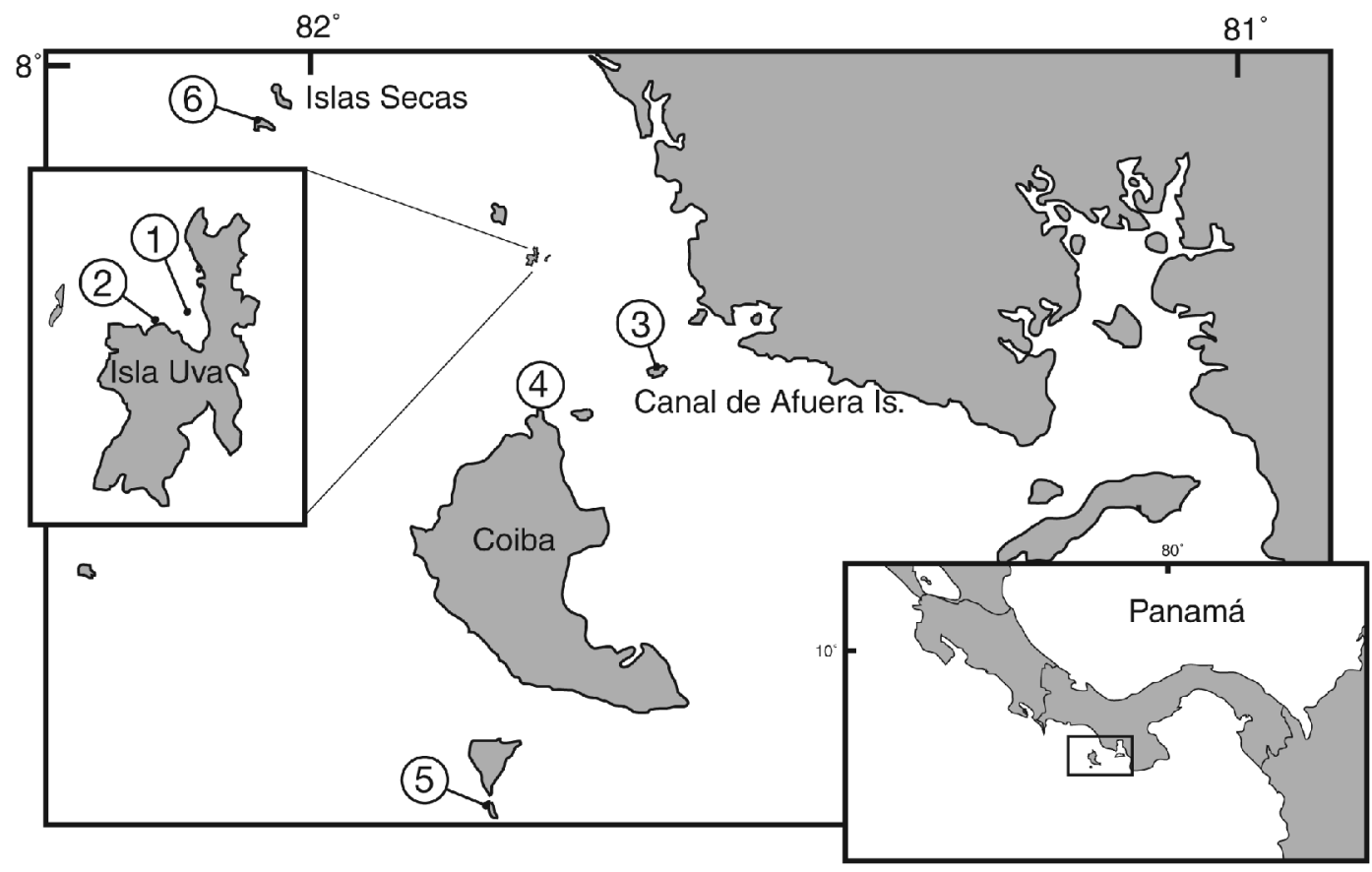

Figure 1. Dolabella auricularia collection sites in the Gulf of Chiriquí, Panamá. 1, Uva Island coral reef; 2, south shore of Uva Island embayment; 3, Canal de Afuera Island; 4, north shore of Coiba Island; 5, Jicarita Island; 6, coral reef on unnamed island in the Secas Islands group.

DVR (Archos 504) and was positioned to record the symbionts. An aquarium divider was used to constrain the symbionts within the field of view. Video files were later uploaded to a computer and symbiont activity was subsequently observed.

The total body lengths (TL) of Carapus preserved in $70 \%$ ethanol were measured to the nearest millimeter. Live body lengths and weights of 27 specimens of Dolabella were obtained within a few hours after capture. Length measurements were taken from naturally relaxed individuals and weights from animals blotted for about $30 \mathrm{sec}$ with absorbent paper towel. A least squares regression analysis was performed on these 27 individuals. The weights of nine individuals were estimated from their lengths according to the regression relationship noted.

Four individuals each of Dolabella and Carapus preserved in $70 \%$ ethanol were dissected to determine the condition of the ctenidia and other organs, and gut contents, respectively. All of these specimens were living together. Two of the opisthobranch hosts were from field-collected (March 2005) specimens. The remaining two hosts and four fish symbionts were collected 18-22 March 2006 at Uva Island and remained together in aquariums for about 3 months. Specimens of $C$. mourlani are deposited in the Ichthyology Department of the California Academy of Sciences (CAs), San Francisco, California, and the Virginia Institute of Marine Sciences (vims), Glouster Point, Virginia. Included are CAS 225463 (85 mm TL); CAS 225464 (84 mm TL); CAS 225465 (85 mm TL); CAS 225466 (68 mm TL); CAS 225467 (77 mm TL); CAS 225468 (73 mm TL); CAS 225469 (82 mm TL); CAS 225471 (87 mm TL); CAS 225472 (76 mm TL); CAS 225473 (87 mm TL); vims 12001 (TL not measurable); viMs 12002 (71 mm TL); vims 12003 (74 mm TL); and vims 12004 (71 mm TL). 
TABLE 1

Numbers of Carapus mourlani Found in Association with Dolabella auricularia Collected from Rubble Bags at 4-6 m Depth on the Seaward Front of the Uva Island Coral Reef, 2002-2005

\begin{tabular}{|c|c|c|c|c|c|}
\hline Location on $\operatorname{Reef}^{a}$ & Date & No. Dolabella & No. Carapus & Car./Dol. ${ }^{b}$ & Mean Prevalence \\
\hline \multirow[t]{5}{*}{ North } & 19 Sept. 02 & 1 & 0 & - & \\
\hline & & 1 & 0 & - & \\
\hline & 7 Mar. 04 & 8 & 1 & 1 & \\
\hline & 9 Mar. 05 & 1 & 0 & - & \\
\hline & 10 Mar. 05 & 4 & 0 & - & 0.067 \\
\hline \multirow[t]{7}{*}{ Center } & 4 Mar. 03 & 1 & 1 & 1 & \\
\hline & & 4 & 1 & 1 & \\
\hline & & 3 & 0 & - & \\
\hline & 15 Sept. 03 & 2 & 0 & - & \\
\hline & 10 Mar. 05 & 1 & 2 & 2 & \\
\hline & 11 Mar. 05 & 4 & 1 & 1 & \\
\hline & 12 Mar. 05 & 4 & 0 & - & 0.263 \\
\hline \multirow[t]{7}{*}{ South } & 17 Sept. 02 & 5 & 1 & 1 & \\
\hline & 9 Mar. 03 & 10 & 2 & 1 & \\
\hline & 14 Sept. 03 & 1 & 1 & 1 & \\
\hline & 13 Mar. 04 & 6 & 5 & $1,2,2$ & \\
\hline & 15 Mar. 05 & 2 & 0 & - & \\
\hline & & 7 & & ? & 0.419 \\
\hline & & & \multicolumn{2}{|c|}{ Overall mean prevalence } & 0.292 \\
\hline
\end{tabular}

${ }^{a}$ North, center, and south sectors of reef.

${ }^{b}$ Denotes number of Carapus per host when inquiline was present.

\section{RESULTS}

On the Uva Island coral reef, the overall mean prevalence of adult Carapus mourlani with Dolabella auricularia was 0.292 (Table 1; Figure 1, site 1). The prevalence of the symbiosis was highest at the south end of the reef (0.419) compared with the north (0.067) and central (0.263) reef sectors. Most Dolabella $(n=8)$ hosted single individuals, but three different hosts contained two fish each. Dolabella collected at night (March 2005, 01000200 hours; March 2006, 2100-2200 hours) while grazing along the coral/rock bottom of the south shore embayment (Figure 1, site 2) exhibited a prevalence of 0.22 (4 Carapus $/ 18$ Dolabella). Three C. mourlani were associated with nine Dolabella (prevalence $=0.33$ ) collected during the day from under pocilloporid blocks along the leeward side of Uva reef. The carapid inquiline was also found inhabiting D. auricularia by D. R. Robertson (pers. comm.) in 2003 at Canal de Afuera Island and along the north shore of Coiba Island (Figure 1, sites 3, 4), and by Terence M. Gos- liner at Isla Jicarita in 2003 (Figure 1, site 5). The presence of Carapus was determined by introducing Quinate (active ingredient quinaldine) to the mantle cavity. Six adult $C$. mourlani were found by Robertson inhabiting D. auricularia collected from under rock scree with a prevalence of $\sim 0.01$. Finally, 22 Dolabella were collected in March 2003 from under coral blocks at $1 \mathrm{~m}$ depth on a reef flat in the Secas Islands (Figure 1, site 6), but none of these contained the inquiline. Only two tenuis-stage larvae were found over the course of this study. They were collected from Dolabella in rubble bags on March 2003 from central and south Uva reef locations.

Euapta godeffroyi (Semper), the only other large abundant holothurian at the study site, did not host $C$. mourlani. Examination of 60 individuals of $E$. godeffroyi collected from rubble bags across the reef front during 2002-2005 did not reveal associated carapids. Numerous specimens of Acanthaster planci, another potential host, were examined and dissected at the Uva reef and from other localities in the Gulf of Chiriquí from 1970 to 


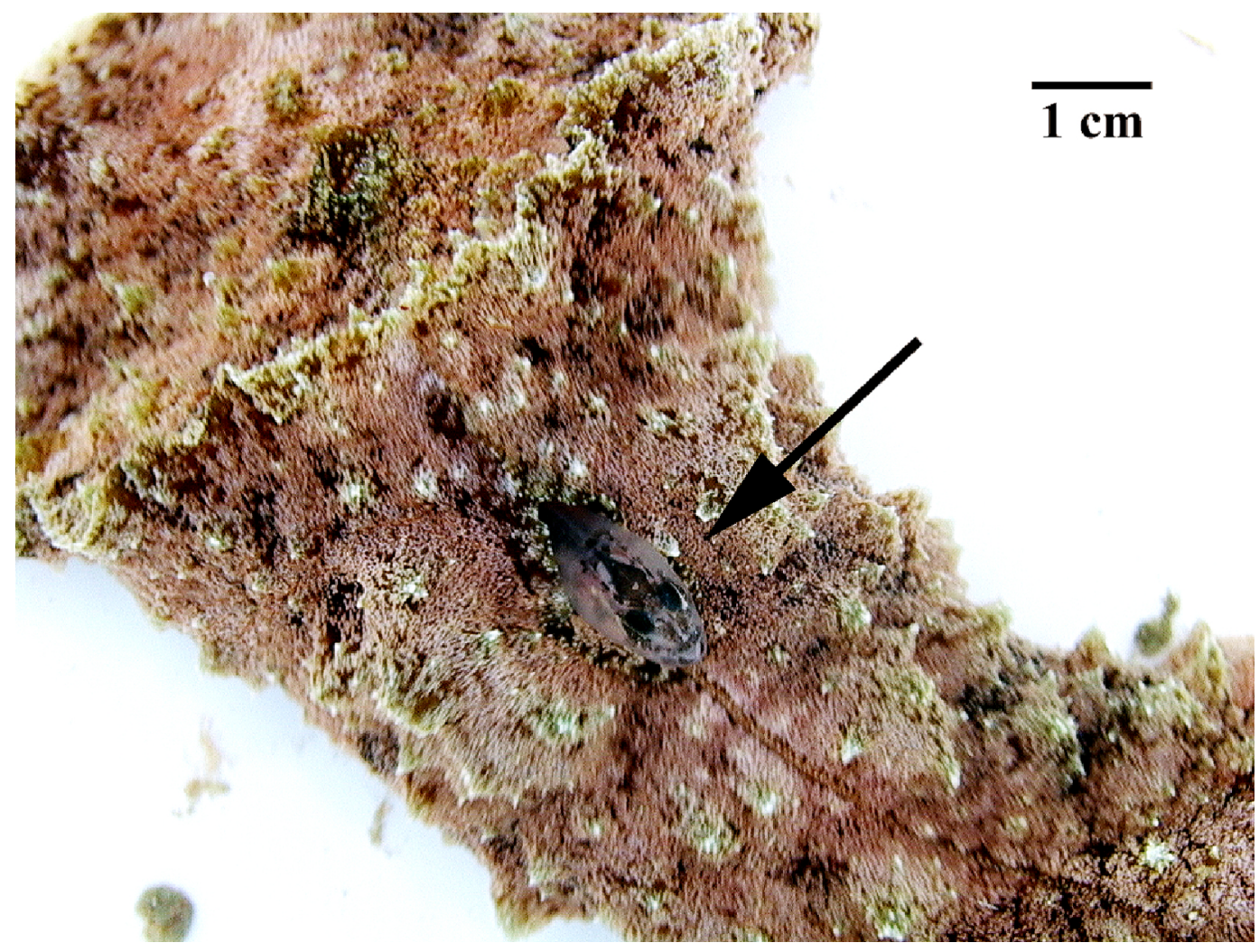

Figure 2. Head of Carapus mourlani protruding from inhalant siphon of Dolabella auricularia (arrow) recently collected at the Uva Island coral reef, March 2004.

2006. Carapus was not found in that species either.

Field observations of recently captured fish showed them to enter the host's mantle cavity headfirst through the anteriorly located inhalant siphon. However, on several occasions fish explored the inhalant siphon area headfirst then quickly inserted their tails and backed in to the mantle cavity tail first. This tail-first entry was executed quickly, in from 2 to $\sim 25$ seconds, by vigorous body wriggling (Figure 2). A few fish were observed to exit their hosts headfirst from the exhalant siphon. In no instance did the activities of Carapus cause Dolabella to contract or release ink. Video records $(n=13, \sim 12 \mathrm{hr}$ nocturnal observations each) over a 4-month period (November-March) showed a hidden fish to emerge headfirst from the inhalant siphon after sunset and enter the exhalant siphon headfirst after varying times of freeswimming activity. The times outside the host varied from 24 to $587(9.8 \mathrm{hr}) \mathrm{min}$. On two occasions, fish exited and entered its host twice. During 10 nocturnal video records over a 2.5-month period, Carapus failed to emerge from its host.

Fifteen C. mourlani collected from Dolabella in rubble bags over the period 10-15 March 2005 had ethanol-preserved mean (1 SD) lengths and wet weights, respectively, of $81.3(6.9) \mathrm{mm}$ and 0.83 (0.32) g. Total lengths ranged from 68 to $97 \mathrm{~mm}$ and weights from 0.315 to $1.534 \mathrm{~g}$. The Dolabella lengthweight relationship for 27 individuals (Figure 3 ) is expressed as the power function $y=$ $0.040 X^{3.271}\left(r^{2}=0.893\right)$. Nine individuals with known lengths only are also plotted in 


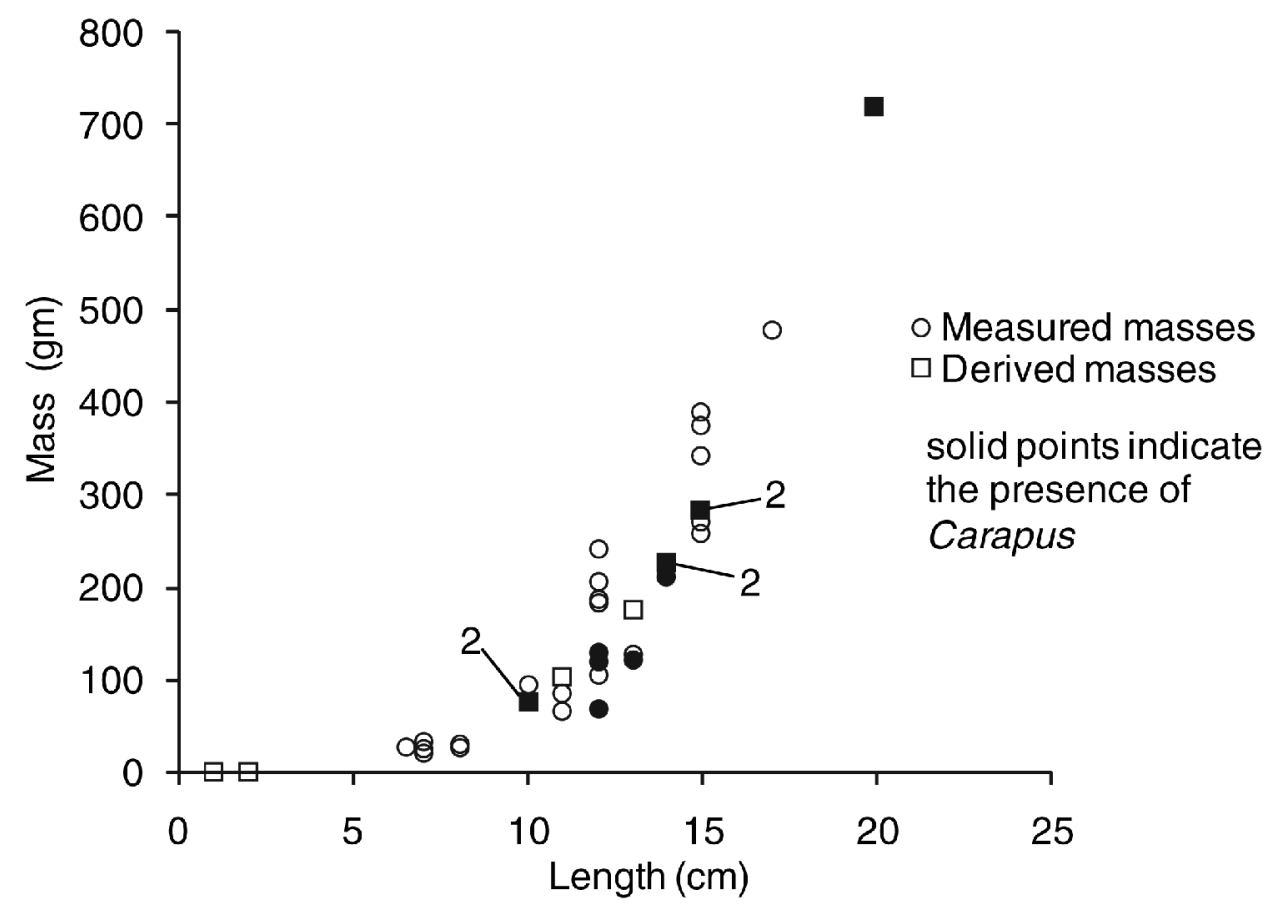

Figure 3. Body length and mass relationship of live Dolabella auricularia collected at the Uva Island coral reef $(n=36)$. Solid symbols denote Dolabella hosts with Carapus mourlani. The number 2 identifies hosts that contained two fish symbionts.

Figure 3. Carapids occurred with Dolabella over a wide range of host sizes, from 10 to $20 \mathrm{~cm}$ in length. The smallest and largest $D_{0-}$ labella hosts contained two and one C. mourlani, respectively. The two tenuis larvae were 143 and $153 \mathrm{~mm}$ in length. Their specific hosts could not be identified.

Upon visual inspection of four dissected Dolabella that hosted carapids, none revealed damage to tissues lining the mantle cavity or damage to the ctenidium, digestive gland, gonad, and kidney (Figure 4). Another indication that the host's gonads were not impaired is from reproductively active Dolabella harboring the fish inquilines. On 13 March 2004, six Dolabella hosting five carapids at the south end of Uva reef were aggregated and laying large masses of eggs.

On several consecutive nights (4-13 March 2007), the infrared video recordings showed $C$. mourlani feeding on swimming crustaceans that had emerged from a rock covered with the brown alga Stypopodium zonale. Amphipods, 4-6 mm in body length, were captured as they swam rapidly upward from the algal substrate. The carapid quickly sensed the location of the amphipod in nearly total darkness, from distances of 2 to $4 \mathrm{~cm}$. In some instances, detection seemed to involve the swimming motion of the prey because the fish was oriented in the opposite direction. Adult carapids such as $C$. mourlani have a moderately developed lateral line and cephalic pore system that would allow the detection of such prey movements. The fish grasped each amphipod and crushed and swallowed body parts. On a few occasions, amphipods were captured, momentarily chewed, and then rejected. Other swimming crustaceans (ostracods and mysids) also were detected, captured, and ingested. Multiple feedings per night were observed. One night a carapid captured and ingested five crustaceans. 


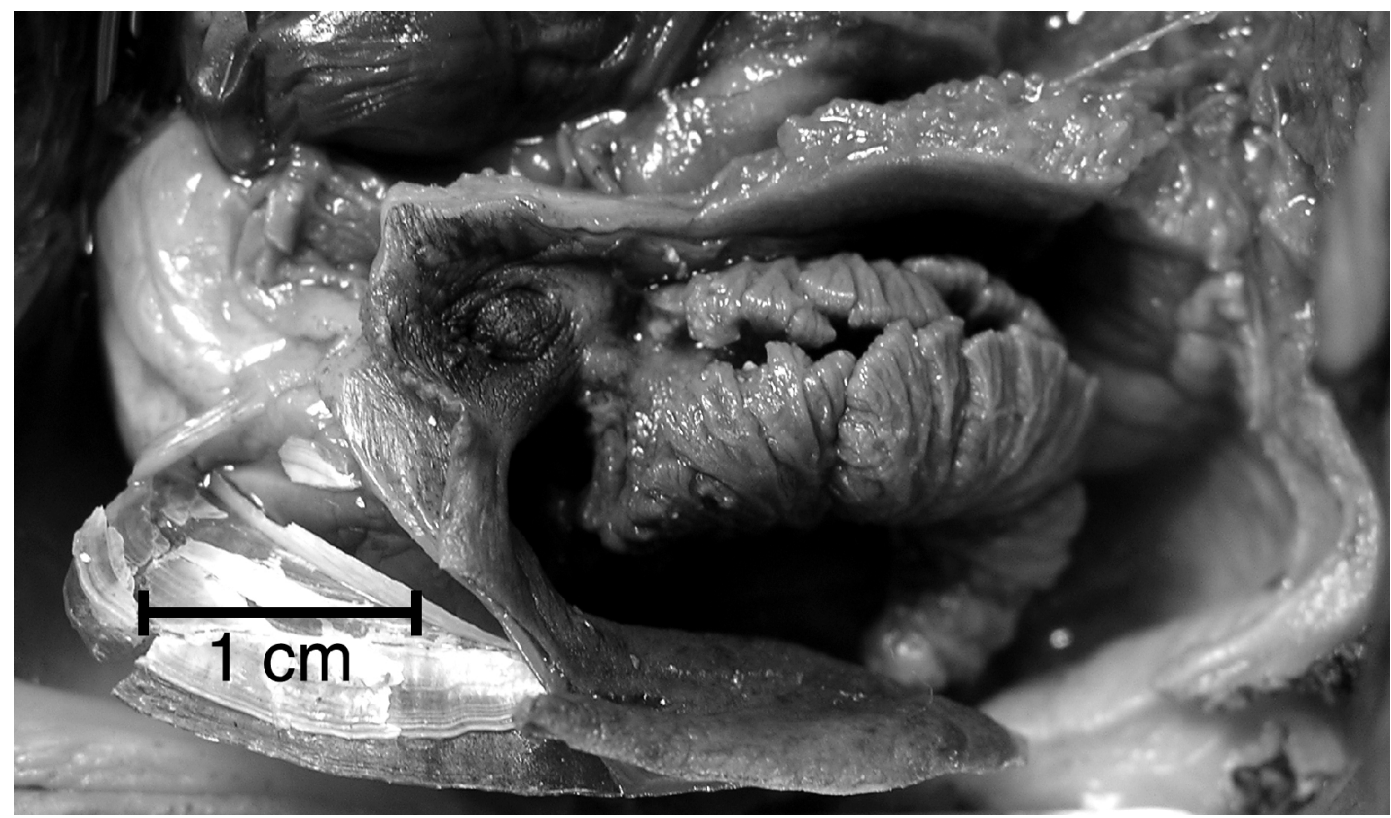

FIgURE 4. Dissected mantle cavity of Dolabella showing exposed, undamaged ctenidium. A Carapus sheltered in this aquarium-confined host for about 3 months.

Examination of the adult buccal cavity revealed well-developed dentition with numerous backward-directed, needlelike teeth on the upper and lower jaws. The two or three teeth anteriorly on the vomer are stout and large, and located along the midline of the roof of the mouth. The same arrangement of teeth was present but less well developed in the tenuis larval stage.

\section{DISCUSSION}

The presence of two fish per host is not uncommon among carapid symbioses. As many as 15 and 19 Carapus mourlani, respectively, were reported in single individuals of a holothurian and an asteroid species (MeyerRochow 1977). At least one of the fish was present in the holothurian's coelom. It is likely that the paired C. mourlani found in Dolabella in our study were of the opposite sex, although this was not verified (Trott 1981).

The relatively large and nearly totally enclosed mantle cavity of Dolabella renders this a suitable resting space for Carapus. The con- stant supply of inhalant water that irrigates the single ctenidium, over which Carapus is coiled, ensures a sufficiently oxygenated medium. Besides benefiting from the shelter provided by Dolabella, it is possible that the host's grazing activities on algal substrates expose mobile microfauna that can then be more readily detected and consumed by the pearlfish. This would be ecologically equivalent to hamlets that follow parrotfish and surgeonfish schools, feeding on invertebrates and fishes flushed from algal turfs by the grazing herbivores (Ogden and Buckman 1973). Meyer-Rochow (1979) suggested that some hosts of $C$. mourlani may offer a source of prey. For example, the cushion sea star Culcita, a common host of pearlfish in the central and West Pacific, generally shelters shrimp that may be consumed by Carapus. No invertebrate commensals were observed on Dolabella.

Another possible advantage of Carapus sheltering in Dolabella is the ability of this herbivore host to sequester noxious secondary metabolites from its algal diet. The con- 
centration of unpalatable chemicals would likely render Dolabella less likely to be consumed by potential reef predators. Pennings et al. (1999) demonstrated from feeding assays on reefs at Guam that the skin, eggs, and digestive glands of $D$. auricularia were unpalatable to reef fishes. The opisthobranch's ink also likely plays a role in chemical defense, due to the concentration of a dietary-derived red algal pigment (aplysioviolin). The unpalatable nature of the host's tissues might also discourage feeding by the fish symbiont.

A study conducted in the South Moluccan Sea, based on gut analyses of adult C. mourlani associated with echinoderms (asteroids and holothurians), demonstrated that decapod crustaceans, probably polychaetous annelid worms, and small fishes were consumed by the symbiont (Meyer-Rochow 1979). Another line of evidence, from the stable isotopic composition of adult muscle tissue of $C$. mourlani living in the coelomic cavity of a cushion sea star in French Polynesia, supports the earlier findings of a nonparasitic association (Parmentier and Das 2004). Our results, of nocturnal feeding on crustaceans and no apparent damage to the opisthobranch host's internal organs, also support those studies. Two tenuis-stage larvae were found with $D_{0}$ labella, but we were not able to determine their feeding habits. Jangoux (1974) noted that the young stages of $C$. bomei (Richardson) are more inclined to parasitism than adults, consuming the gonadal tissues of their asteroid hosts. This claim is suspect, however, because his description of the fish is incorrect, and $C$. bomei does not inhabit asteroids and is not parasitic.

Acanthaster planci occurs at the Uva reef, sometimes at relatively high population densities (25-30 individuals $\mathrm{ha}^{-1}$ ) but has not been observed hosting $C$. mourlani as in the western Pacific (Cheney 1973). On Guam, $A$. planci is probably not a major host of Carapus because only around $1 \%$ of 450 sea stars contained the inquiline. The only large holothurian present at the Uva reef is Euapta godeffroyi, but $C$. mourlani has not been found to inhabit this species either. It is possible that the sticky body wall and tentacles of $E$. godef- froyi, due to the presence of anchor ossicles, would offer an entanglement hazard to Carapus.

The ability of Carapus mourlani to feed under subdued light conditions demonstrates a capacity to detect and capture rapidly moving prey at night. Meyer-Rochow and Tiang (1978) showed that the eyes of C. mourlani are fully functional and concluded (p. 583) "that the eye of $C$. mourlani is basically a photoreceptor designed for vision in a dark environment characterized by high sensitivity and poor resolution, but that its visual performance drops with age." It is also possible that the swimming activities and pressure changes generated by potential prey serve to alert $C$. mourlani of a feeding opportunity.

Considering the nocturnal feeding behavior, visual sensitivity under low-light conditions (Meyer-Rochow and Tiang 1978), and the adaptations of the buccal apparatus for feeding, it is likely that the diurnal association of Carapus mourlani with a variety of hosts evolved in response to avoid visual predators. Based on the structural and behavioral specializations in feeding, adult $C$. mourlani can be justifiably placed among grasping hunters.

\section{ACKNOWLEDGMENTS}

John E. Olney kindly identified the carapid species. We thank Tyler B. Smith and Juan L. Maté for photographic help, and C. M. Eakin, Vincent Flynn, Peggy Fong, Gena Hockensmith, Derek Manzello, and Matt Whartian for field and laboratory assistance. The feeding and maintenance of animals was performed by Tara Dolan, Carla Fernández, Tally Holcombe, Daniel Holstein, Lindsay Jones, Margarita Kruyff, Megan Porter, and Erin Reilly. Jonathan Walkenstein (Nonlinear Dynamics Laboratory, University of Miami) and Aaron Jozsef offered technical advice on the IR illuminator and camera design. Information on Carapus mourlani collections from Panamá were provided by D. R. Robertson and Terence M. Gosliner. Permission to work and collect specimens in the Coiba National Park was authorized by the Autoridad Nacional del Ambiente (ANAM), 
Republic of Panamá. Scientific export permits were granted through the Ministerio de Desarrollo Agropecuario (MIDA) permit nos. 46099 and 72423, and SEX/A-23-05 and SEX/AP-2-06 (ANAM). The Smithsonian Tropical Research Institute also provided laboratory and logistical support.

\section{Literature Cited}

Ayling, T., and G. J. Cox. 1982. Collins guide to the sea fishes of New Zealand. William Collins Publishers Ltd., Auckland, New Zealand.

Camacho-García, Y., T. M. Gosliner, and Á. Valdés. 2005. Field guide to the sea slugs of the tropical eastern Pacific. California Academy of Sciences, San Francisco.

Castro, P. 1988. Animal symbiosis in coral reef communities: A review. Symbiosis 5:161-184.

Cheney, D. P. 1973. Pearlfish (Carapidae) in Acanthaster planci (L.). Micronesica 9:159.

Gosliner, T. M., D. W. Behrens, and G. C. Williams. 1996. Coral reef animals of the Indo-Pacific. Sea Challengers, Monterey, California.

Jangoux, M. 1974. Sur 1'“association" entre certaines astéries (echinodermata) et des poissons Carapidae. Rev. Zool. Afr. 88:789-795.

Markle, D. F., and J. E. Olney. 1990. Systematics of the pearlfishes (Pisces: Carapidae). Bull. Mar. Sci. 47:269-410.

Meyer-Rochow, V. B. 1977. Comparison between 15 Carapus mourlani in a single holothurian and 19 C. mourlani from starfish. Copeia 1977:582-584.

- 1979. Stomach and gut content of Carapus mourlani from starfish and a holothurian. Ann. Zool. Fenn. 16:287-289.

Meyer-Rochow, V. B., and M. K. Tiang. 1978. Visual behavior, eye and retina of the parasitic fish Carapus mourlani. Biol. Bull. (Woods Hole) 155:576-585.

Ogden, J. C., and N. S. Buckman. 1973.
Movements, foraging groups, and diurnal migrations of the striped parrotfish Scarus croicensis Bloch (Scaridae). Ecology 54: 589-596.

Paredes-Rios, G. A., and E. F. Balart. 1999. Corroboration of the bivalve, Pinna rugosa, as host of the Pacific pearlfish, Encheliophis dubius (Ophidiiformes: Carapidae), in the Gulf of California, México. Copeia 1999:521-522.

Parmentier, E., and K. Das. 2004. Commensal vs. parasitic relationship between Carapini fish and their host: Some further insight through $\delta^{13} \mathrm{C}$ and $\delta^{15} \mathrm{~N}$ measurements. J. Exp. Mar. Biol. Ecol. 310:47-58.

Parmentier, E., A. Mercier, and J. Hamel. 2006. New host and geographical distribution for the pearlfish Carapus mourlani (Carapidae) with a discussion of its biology. Copeia 2006:122-128.

Parmentier, E., and P. Vandewalle. 2005. Further insight on the Carapiniholothurian relationships. Mar. Biol. (Berl.) 146:445-465.

Pennings, S. C., V. J. Paul, D. C. Dunbar, M. T. Hamann, W. A. Lumbang, B. Novack, and R. S. Jacobs. 1999. Unpalatable compounds in the marine gastropod Dolabella auricularia: Distribution and effect on diet. J. Chem. Ecol. 25:735-755.

Svetovidov, A. N. 1961. On European species of the family Ophidiidae and on the functional importance of the structure specificity of their fish sound. Vopr. Ikhtiol. 17:313.

Trott, L. B. 1970. Contributions to the biology of carapid fishes (Paracanthopterygii: Gadiformes). Univ. Calif. Publ. Zool. 89:1-60.

. 1981. A general review of the pearlfishes (Pisces, Carapidae). Bull. Mar. Sci. 31:623-629.

Williams, J. T., and R. L. Shipp. 1982. A new species of the genus Echiodon (Pisces: Carapidae) from the eastern Gulf of Mexico. Copeia 1982:845-851. 
